\title{
THE POSITION OF ISLAM NUSANTARA IN GEOPOLITICAL DINAMYCS OF ISLAMIC WORLD
}

\author{
Abdul Chalik \\ Fakultas Ushuluddin dan Filsafat UIN Sunan Ampel \\ Jl. Jend. A. Yani 117 Surabaya, 60237 \\ e-mail: achalik_el@yahoo.co.id
}

\begin{abstract}
During the weakening of bargaining position of Islam in world's view because of terrorism issue after the 'Black September 2001', ISIS arise, a socio-political organization that is even more extreme than the predecessor, al-Qaeda. ISIS not only make the West afraid because of all the exploitation, especially after the Paris terror in the mid of November 2015, but also hurt the feeling of Muslims as they involve the name of Islam-while the behavior is contrary to the belief in Islam. Geopolitically, the position of Islamic world is in dilemma; one side it must deal with the Muslims, while on the other side it should be in synergy with foreign powers against its own nation or brothers. The Islamic world position to face the power of ISIS is weak. Different from ISIS or al-Qaeda which is extreme and exclusive, Islam Nusantara is on the contrary. This article was written by a descriptive-explorative method by presenting the issues of the Islamic world today and its relationship with the ideology of Islam Nusantara being built.
\end{abstract}

\begin{abstract}
Abstrak: Peranan Islam Nusantara dalam Dinamika Geopolitik Dunia Islam. Tulisan ini berangkat dari kegelisahan terhadap lahirnya ISIS, sebuah gerakan sosial politik yang lebih ekstrim dibandingkan dengan pendahulunya, al-Qaeda. Satu sisi, organisasi ini tidak saja membuat Barat ketakutan atas segala sepak terjangnya, terutama pasca teror Paris di pertengahan Nopember 2015, pada sisi yang lain juga menciderai perasaan umat Islam karena dianggap mendompleng atas nama agama (Islam)—sementara perilakunya berlawanan dengan ajaran Islam. Secara geopolitik posisi dunia Islam mengalami dilema; satu sisi harus berhadapan dengan Muslim sendiri sementara pada sisi yang lain harus bersinergi dengan kekuatan asing untuk melawan bangsa atau saudara sendiri. Berbeda dengan Islam ala ISIS atau al-Qaeda yang bercorak ekstrim dan eksklusif, Islam Nusantara berpandangan sebaliknya. Artikel ini ditulis dengan metode ekploratif deskriptif_-dengan menyajikan persoalan dunia Islam saat ini dan hubungannya dengan ideologi Islam Nusantara yang sedang dibangun.
\end{abstract}

Keywords: Islam Nusantara, Islamic world geopolitics, ISIS 


\section{Introduction}

Islam, as a universal religion that is mentioned in al-Qur'an as rahmat li al-'âlamîn, has a universal doctrine related to the place and time where it is developed. ${ }^{1}$ Therefore, the existence of the term 'Islam Nusantara' is not necessarily to be sensational. That term is not different from Islam in Arab, Islam in Iran, and Islam in Egypt, which indicate the development of Islam in each country. Islam Nusantara was not born in emptiness, but there are studies and in-depth understandings about its concept. Nahdlatul Ulama (NU) expects that Islam Nusantara can be the rule model of Islamic world civilization because it is a concept of Islamic thinking that has been developed since the preaching of Walisongo in the archipelago. ${ }^{2}$

Islam Nusantara is often understood simply as Islam that highly appreciates the culture of a region. It means that the culture existed in a region will not be abolished instantly but it will be preserved with a new form which is acculturated with the teaching of Islam based on al-Qur'an and Hadis. ${ }^{3}$

The reaffirmation of Islam Nusantara rediscovers the significant relevance in the mid-crisis of Islamic ideology; rahmat li al-'âlamîn which is eroded. Globalization in all aspects gives great impacts to the shift of Islamic mindset as the result of varied influential thoughts in Islamic world. Fundamentalism which is always defined as the presence of radicalism in Islam is a problem of Islamic movement that intimidates the enthusiasm of rahmat li al 'alamîn Islam. ${ }^{4}$ Moreover, the transnational political ideas that expect the presence of Islamic Caliphate have found a place in people' hearts, though the historical reference of the caliphate concept actually is still questionable. Islamic caliphate system had ever existed, but it does not mean that they all had the same concept. Every different concept gives different advantages and disadvantages. ${ }^{5}$ The effect of the concept then causes less sympathetic response from the Muslim society.

It is because the love of Muslims to their country has actuated their nationalism as the integrated part of the religious spirit. One of the example is "Resolusi Jihad" as one of the ijtihâd of Ulama' regarding the importance of loving the homeland. ${ }^{6}$ Therefore, when

${ }^{1}$ M. Imdadun Rahmat, Islam Pribumi: Mendialogkan Agama dengan Realitas (Jakarta: Erlangga, 2003), p. 2.

${ }^{2}$ Nur Syam, Islam Pesisir (Yogyakarta: LKiS, 2005), p. 70.

${ }^{3}$ Uka Tjandrasasmita, Arkeologi Islam Nusantara (Jakarta: Gramedia, 2009), p. 323.

${ }^{4}$ Muhammad Hamdi Zaqzuq, Reposisi Islam di Era Globalisasi (Yogyakarta: Pustaka Pesantren, 2001), p. 10.

${ }^{5}$ Abdul Chalik, Islam dan Kekuasaan: Dinamika Politik dan Perebutan dalam Ruang Negara (Yogyakarta: Interpena, 2012), p. 16.

${ }^{6}$ In order to maintain the freedom as a form of love to the homeland, the Kiai who have published the fatwa "Holy War" (Resolusi Jihad) against England and Netherland. That fatwa encourage the people, exactly in Surabaya and East Java, to fight against the colonialism together. 
the transnational idea appears, Muslims in Indonesia who understand the history of the country would easily oppose the religious fundamentalism, both radical in syariah or in politic. Since Islam Nusantara has become the main topic of Nahdlatul Ulama at the $33^{\text {rd }}$ Mukmatar in Jombang, the movements of Islam Nusantara is getting stronger. However, the fundamentalists automatically oppose that idea because according to them the presence of Islam Nusantara is considered as a new ideology that castrates a universal Islam. There is a fallacy in their view. They think that the term Islam Nusantara is exploitation to Islam as a merciful religion for the universe that only use the concept of archipelago.

There is a spirit that should be highlighted in understanding the term Islam Nusantara. Islam Nusantara is another term of Islam as rahmat li al-'âlamîn. Islam Nusantara is the ijtihâd of Islamic thoughts among the challenges of Islamic world that are getting bigger. Nowadays, the threats for the glory of Islam are not only from outside but also from the inside of Islam itself. The bias of religion thought, which is radical-fundamentalist all this time, has screwed Islam from within. ${ }^{7}$ In real word, as a concrete example, the terrorism driven by activists of al-Qaeda is a form of fundamentalist ideology that is basing the religious views on the radical texts without comprehensively understanding the whole dogma of Islam. A whit more from al-Qaeda, Islamic State of Iraq and Syria (ISIS) is also be sensational to the world because of their brutal actions not only for non-Muslims, but also for the Muslims. ${ }^{8}$

Al-Qaeda and ISIS has become threats to the Islamic world, especially in this digital era where the information moves rapidly. Therefore, it will be very easy for radical fundamentalist ideology to involve the others Islamic societies, including Indonesia. ${ }^{9}$ In many reports, there are many Indonesian Muslims have been attracted by the idea of ISIS. They believe that the concept developed by ISIS is the right way. However, if ISIS handles our country, the threat of Indonesia's integrity as a sovereign citizen will be stronger. Pancasila as a collective ideology across religions and ethnic groups is part of ijtihâd created by Ulama' of Islam Nusantara in the past. They put religion as a historical moral spirit in order to strengthen the unity of the complex people. The term Ketuhanan Yang Maha Esa is the embodiment of Islamic theology ilâh al-wâhid. ${ }^{10}$ Therefore, the Ulama' try to make Islam Nusantara as a modern religion sect not only in Indonesia, but also in the world. As the

Look at, Ali Maschan Moesa, Nasionalisme Kyai: Konstruksi Sosial Berbasis Agama (Yogyakarta: LKiS, 2007), p. 116.

${ }^{7}$ Bassam Tibi, The Challenge of Fundamentalism: Political Islam and the New Disorder, (Berkeley: University of California Press, 1998), p. 2.

${ }^{8} \mathrm{M}$. Anwar Surahman \& Marye Agung Kasmagi, Konspirasi Amerika Serikat Memata-Matai Dunia Versi Wikileaks (Jakarta: Raih Asas Sukses, 2011), p. 160.

${ }^{9}$ Greg Fealy \& Anthony Bubalo, Jejak Kafilah: Pengaruh Radikalisme Timur Tengah di Indonesia, transl. Akh Muzakki (Bandung: Mizan, 2007), p. 9.

${ }^{10} Y u d i$ Latif, Negara Paripurna: Rasionalitas, Historisitas, dan Aktualitas Pancasila (Jakarta: Gramedia, 2011), p. 627. 
idea of Islam in Indonesia, Islam Nusantara can embody Islam as rahmat li al-'alamîn with the dynamic of various times and places because their concept is maintaining the good old traditions and taking the better new tradition (al-muhâfadhah 'ala al-qadîm alshâlih al-akhdzu bi wa al-jadîd al-ashlâh). ${ }^{11}$

This paper is going to examine the substance of Islam Nusantara, geopolitical world today and how the relationship between the ideology of Islam Nusantara with the development of ideology of the Islamic world. The issue is to be developed, whether it can even become an alternative over-the ideology of Islamic ideology by offering moderatisme, tolerant and friendly to other groups.

\section{Islam Nusantara, Universal Islam}

The persistency of Muslims in Indonesia, on the rule of al-muhâfadhah 'ala al-qadîm al-shâlih al-akhdzu bi wa al-jadîd al-ashlâh, is kind of universal definition from raḥmat li al-'alamin. As a universal religion, Islam requires the ijtihâd for in context of space and time where Islam is developed. Heading toward religious values by emphasizing common benefits is the most important foundation. Historically, Islam Nusantara as a manifestation of universal Islam always proselytizes kindly. The traditions of Islam Nusantara such as tahlîl, celebration, and prayer for the death are considered as the acculturation of the previous religions' culture by internalizing the ideas of Ulama' archipelago without patronizing. They can put the dogma of Islam universally, so that people will accept it easily.

As a universal religion, the dogma of Islam crosses the timelines and countries. Therefore, some cultural crushes will be difficult to be avoided if Islam is only understood as tradition of Arab. As a religion that originally comes from Arab with the Holly Qur'an written in Arabic, Islam is mostly manifested with Arabic tradition. But it does not mean that Islam is always defined as Arab tradition. According to Fazlur Rahman, Islam brings the moral spirit from Arab, but not for the tradition. ${ }^{12}$ Therefore, globally, Islam is always appropriate to the dynamical of place and time.

Being appropriate to the dynamic place and time is the reality and challenge for Islam to keep the existence because religion is used as a set of values and life guidance for human being. Therefore, it can be concluded explicitly that people need religion and religion must exists based on the requirements and demands of the followers.

Islam is not only a theological doctrine of religion, but also universal for all the aspects of life. According to Kuntowijoyo, there is no dichotomy about world life or beyond life in

${ }^{11}$ Zuhairi Misrawi, "Meneguhkan Islam Nusantara," in Kompas (Sabtu, 1 Agustus 2015), 6.

${ }^{12}$ The term of moral value used by Fazlur Rahman in his thought about the hermeneutic of the al-Qur'an, as construction to understand the universality of the dogma in the al-Qur'an. Look at, Ahmad Syukri Saleh, Metode Tafsir al-Quran Kontemporer dalam Pandangan Fazlur Rahman (Jakarta: Gedung Persada Press, 2007), p. 83. 
Islam. Islam values are essentially all-embracing to the structure of social, politics, economics, and cultures. ${ }^{13}$ To make Islam historically developed in society, Muslims really need ijtihâd in defining Islam as a universal religion which is the truth can be meaningful when it is applied in society. According to Ulil Absar Abdalla, Muslims must do ijtihâd to find new formulas in defining those values, especially for their own life. ${ }^{14}$ So that the existence of religion will be meaningful and Islam will not lose the identity as a merciful religion to the universe.

Nowadays, the challenges of Islam are radicalism and terrorism that come from the fundamentalism which is understood superficially. The radicalist and terrorist recognize religion as if it allows violence doctrine. Meanwhile, as a civilized religion, Islam never exclaims violence to be a solution. ${ }^{15}$ The expectation of Islam is all the followers have the spirit of knowing each other as a civility of dialogue in understanding the reality of all diversities. The Muslims who believe in radical-fundamentalism view often conceal themselves from the outside, moreover from them who appreciate the different Islamic sects and the other religions mentioned in al-Qur'an.

That attitude is often called exclusive. "Exclusive" is literally defined as lonely, without accompanied by others, separated from others, independent, no relation to others. ${ }^{16}$ Generally, in religion context, the term "exclusive Islam" is defined as Islam sect that conceals themselves from the eyes of others sects or other religions. Based on their claim, people must have the same idea of ISIS, without giving any chance for them to choose their own beliefs. That attitude finally makes the exclusive Muslims conceal themselves from social interaction to other religions.

That view actually is not an example of universal Islam as a merciful religion. Islam requires respect for the upright of life culture, through all the aspects of life, including the right to embrace a religion. Therefore, Muslims need to be wise in defining Islam substantially without emasculating human values as the basic of Islamic rightness. ${ }^{17}$ It is impossible for Muslim, as a universal religion, to emasculate the humanism values as the appreciation of the diversity. In the concept of Islamic theology the truth is determined by God, though it still depends on the will of human freedom. Thus, all differences actually are God's willing. Denying the appreciation for diversities means deny the reality of God's willing.

In the effort of fostering high appreciation to diversity, the inclusive attitude in interfaith interaction is needed. That attitude shows that there is appreciation applied

${ }^{13}$ Kuntowijoyo, Paradigma Islam: Interpretasi untuk Aksi (Bandung: Mizan, 1991), p. 167.

${ }^{14}$ Ulil Absar Abdalla, "Menyegarkan Kembali Pemahaman Islam," in Kompas (Monday, 18 November 2002), p. 6.

${ }^{15}$ Harun Nasution, Islam Rasional (Bandung: Mizan, 1995), p. 124.

${ }^{16} \mathrm{John}$ M. Echols \& Hasan Shadily, Kamus Inggris-Indonesia (Jakarta: Gramedia, 1990), p. 222.

${ }^{17}$ Tobroni dan Syamsul Arifin, Islam Pluralisme Budaya dan Politik (Yogyakarta: Siprees, 1994), p. 35. 
for other religions' followers in expressing their beliefs. In the academic world, there is a term called religious pluralism. This discourse attracts a lot of Muslims because the basic requirement of global society is the high appreciation for diversity. ${ }^{18}$

In academic studies, religious pluralism is defined as an idea of all religions that represent the same truth in the perspective of their own adherents. All of them promise the salvations and happiness, though they use different ways. All religions are equally effective means to salvations, liberation, and happiness. ${ }^{19}$ The spirit built in religious pluralism is actually a respect for everyone to recognize the truth of the religion, but it does not mean to equate the truth of all religions in all perspective. The claim of the religious truth is a right for each religious adherent because there is a guarantee in every religious holy book..$^{20}$ Religious pluralism became a way for the intersection of religions because whatever the concept presented, it lead them to the one God. ${ }^{21}$ Whatever the concept of a religion about their God, the Muslims have their own definition of God that is Allah.

There must be some differences in every aspect.The important thing we should do is respecting those differences as an absolute truth. Pluralism becomes an absolute thing that cannot be denied such a reality that is purposefully created by God as a test for human being. In Muhammad Hamdi Zaqzuqs opinion, Islam is a universal religion that has high appreciation to the kinds and communities of people as a reality that should not block the realization of unity, togetherness, and the ethos of helping each other. Pluralism must be faced as a chance that can give a way for unity. ${ }^{22}$

For further statement, Nurcholish Madjid stated that pluralism or plurality of human being is a fact that has been become God's willing. The holly book also informs that people are created in different regions and ethnics in order to know and to respect each other. Then, plurality increases become pluralism. It is a value system that looks at the pluralism itself positively and optimistically by accepting it as a reality and doing the best thing based on that reality. ${ }^{23}$

The conception withdrawal of theological belief for everybody is the best way to respond the varieties of religious expressions existed in society. Therefore, in social interaction, there will not be religious bias that can break the social relations and integrations. Moreover, in plural society such as Indonesia, that attitude is very important to avoid conflict that can lead to the hostility and the misunderstanding on the dogma of Islam. This attitude

${ }^{18}$ Sayyed Hossein Nasr, The Heart of Islam, transl. Nurasiah (Bandung: Mizan, 2003), p. 65. ${ }^{19}$ Syamsuddin Arif, Orientalis \& Diabolisme Pemikiran (Jakarta: Gema Insani, 2008), p. 82.

${ }^{20} \mathrm{John}$ Hick, Problem of Religious Pluralism (London: The Macmillan Press, 1985), p. 46.

${ }^{21}$ Suhermanto Ja'far, Filsafaf Perennial \& Titik Temu Agama-Agama (Surabaya: Elkaf, 2007), p. 83.

${ }^{22}$ Zaqzuq, Reposisi Islam, p. 122.

${ }^{23}$ Nurcholish Madjid, Islam Doktrin dan Pradaban (Jakarta: Paramadina, 1992), p. xxv. 
has been developed by the 'Ulamâ' of Islam Nusantara and has been historically integrated in the life Muslims in Indonesia.

At least, there are five opinions of the important attitudes of Islam Nusantara that also become the opinion of Nahdlatul 'Ulama'. Those are tasâmuh (tolerant), tawâzun (balance), tawâsut (moderate), ta'adul (justice), and amar ma'rufnahy al-munkâr (commanding the good and forbidding the evil). ${ }^{24}$ Tolerance is presented by NU as an attitude and a high reward for all the diversities. Meanwhile, moderate and fair as the basic of non-extreme attitudes by emphasizing the common benefit. NU is not extreme and usually taking the middle path to solve a problem. Balanced attitude is taken by NU in order to maintain the harmony of life. The concept of Islamic theology between vertical and horizontal worship should be balanced because all forms of worship actually lead to a devotion that is God. The framework built actually is used to enforce the amar ma'ruf by commanding the good and nahy munkar by forbidding the evil. ${ }^{25}$

The religious view creates an energy in Islamic framework; rahmat li al-âlamîn. As a mercy to the universe, Islam must be an oasis for every soul and body. Therefore, there will not be heart warming religion that comes in radicalism or even in brutalism as what has been followed by the hard-line Islam all this time. Afterward, in religious views, Islam Nusantara is a basic representation of the Archipelagos' religious perspective that has rooted for centuries.

According to Azyumardi Azra, Islam Nusantara is a different Islam as the result of interaction, contextualization, indigenization, and vernacular of universal Islam with social realities, cultures and religions in Indonesia. Theologically, Islam Nusantara has some views such as the school Asy'ariyah, the school Syâfi'iyah, and al-Ghazâlî's sufism. Thus, the religious attitudes developed foster the wasâthiyah character; moderate and tolerant. As a historical religious view that has a lot of Islamic legacy, Islam Nusantara will be a renaissance hope of global Islamic civilization. Therefore, the international Muslim communities extremely hope that Indonesia becomes the prototype of Islamic civilization in the contemporary era because of the people's characters that are multicultural, multiethnic, moderate, and much more tolerant than other Muslims in other countries. ${ }^{26}$

Based on Nasaruddin Umar's perception, we have to distinguish between Islam in the archipelago and Islam Nusantara. For him, the connotation of Islam in archipelago is the description of the existence of Islam in archipelago including the historical development, population, and the characteristic. Meanwhile, the connotation of Islam Nusantara concerns

\footnotetext{
${ }^{24}$ Mahrus eL-Mawa, "Teks dan Karakter Islam Nusantara," in NU Online (Monday, 13 April 2015).

${ }^{25}$ Amad Zahro, Tradisi Intelektual NU: Lajnah Bahstul Masail 1926-1999 (Yogyakarta: LKiS, 2004), p. 24.

${ }^{26}$ Azyumardi Azra, "Islam Nusantara adalah Kita," in http:// fah.uinjkt.ac.id, accessed 17th October 2015.
} 
more to the unique attitude and characteristic of Islam in the area of archipelago. Therefore, the experts of Islam in the archipelago do not always understand about the concept of Islam Nusantara. Islam Nusantara involves various scientific disciplines such as ushûl alfiqh, and the interpretation of authoritative quotation or religious text. Islam Nusantara has more relation to the phenomenon of Islam "as the Islam" rather than "as an Islam" 27. Along the way, Islam Nusantara becomes an important part of Indonesian history because it plays an important role in building civilized society.

Therefore, that characters of Islam Nusantara are not formed instantly but it begins from the traditions, cultures, and literatures of Sufi Islam in the beginning of the $16^{\text {th }}$ century. Michael Laffan, in his book entitled The Makings of Indonesian Islam: Orientalism and the Narration of a Sufi Past (2011), explains that the character of Islam in Indonesia is not formed during the colonialism like what has been assumed by many scholars. It is a continuation and a result of the meetings from various traditions, cultures, intellectualisms, and the religions that have interacted since the first arrival of Islam in Indonesia. Therefore, the mixed tradition of Arab, China, India, and Europe creates the wasathiyah character. ${ }^{28}$

The term Islam Nusantara becomes stronger after it becomes the theme of $33^{\text {rd }}$ Congress of Nahdlatul Ulama' as the grand design of world civilization. the greatest aim of NU as the largest mass organization in Indonesia is to make Islam in Indonesia becomes a role model of Islam as rahmat li al-'âlamîn. However, the challenge of Islamic world is getting stronger and stronger. Radicalism and terrorism developed create a bad image of Islam as a merciful religion. Therefore, the concept of Islam Nusantara is needed. The specific characters of Islam Nusantara such as emphasizing moderate, balance, inclusive, and tolerant can be an alternative to build a peace and a harmony Islamic world civilization in any country. However, it does not mean that the other Muslim in other countries must use the same term as 'Islam Nusantara' because Islam Nusantara does not wish to change Islam or any other culture be like archipelago. ${ }^{29}$

Islam Nusantara is a religious paradigm in Indonesia that sets out the mission of Islam rahmat li al-'âlamîn. Thus, in reality, Islam Nusantara actualizes the values of Islam contextually and looks ahead progressively. Islam Nusantara gives a big effect to the ways of thinking, attitudes, and behaviors of Muslims in Indonesia. Therefore, Muslims in Indonesia can apply the sharia of Islam as the civilized social construction, in order to make a safe and a just social order.

${ }^{27}$ Nasaruddin Umar, "Apa Itu Islam Nusantara?," in Republika (Rabu, 05 Agustus 2015).

${ }^{28}$ Azra, "Islam Nusantara," p. 65.

${ }^{29}$ Zainul Milal Bizawie, "Meneguhkan Islam Nusantara," in http://muktamar.nu.or.id, (Jumat, 26 Juni 2015). 


\section{The Geopolitics of Islamic World after al-0aeda and ISIS}

After the Second World Warand the Cold War, there are only three big issues in Islamic world. Those three issues are about Suez, oil, and the revolution of Iran. Graham and Lesser mentioned that those three issues become a diplomatic media of Muslim to face other countries, especially Europe and USA. ${ }^{30}$ The issue of canal Suez has triggered the West countries to collaborate with Egypt and the others countries around it, and then they will make Israel as a puppet that always bother and spy countries in Arab, especially for Egypt that has the important access in canal Suez. In some decades, this issue has become the main topic that hegemonies of mid-East economy in the name of diplomacy and peace guarding.

In addition, the oil issue becomes one of important discussion topics for decades. It has been known that more than $60 \%$ of oil reserves are in Middle East, especially in Arab and Iraq, therefore countries in that area are very rich. The last issue was the resolution of Islam Iraq in 1979 that created a new movement called Islam revivalism under the shade of Ayâtullâh Khomeinî. ${ }^{31}$

In the research of Fuller and Lesser, during the decade in1980 to the middle of 1990, the world issues are still flat. The issues that grow up are more internal and responsive to the dynamic of relation inter political powers. According to Fuller and Lesser, if there are some extreme groups, they will be more cultural and religious struggle. It means that they will struggle with the principles of Islam in the nation. ${ }^{32}$ Though the ways and the reactions are various such as bombing, but it is not considered as a very extreme thing.

Three decades after the Islamic Iran revolution, some groups appear and catch the attention of public world, especially Europe and United State of America that feel mostly threatened by the existence of these organizations; al-Qaeda and Islamic State of Iraq and Syria (ISIS). These organizations become the top issues after the World War II and Cold War.

As an international terrorism connection, al-Qaeda becomes the organization that is frightened by Islam and the fugitive of the world at once. Moreover, after the tragedy of World Trade Center building, in New York, USA in September $11^{\text {th }}$ 2001, Islam was attacked and considered as a terrorist. Therefore, the western's phobia toward Islam is bigger and that the challenge for Muslims to bring the image back is also stronger. It is because in West, Alwi Sihab thinks that Islam is stereotyped. He also thinks Islam is a religion that allows violence, spread by sword, and always be the cause of the terrorism attack. ${ }^{33}$ As a consequence, the existence of al-Qaeda supports that assumption. The presence of Islam

\footnotetext{
${ }^{30}$ Graham E. Fuller \& Ian O. Lesser, A Sense of Siege: the Geopolitics of Islam and the West, (Santa Monica:Westview Press, 1995), p. 21.

${ }^{31}$ Ibid., p. 21-25.

${ }^{32}$ Ibid., p. 168.

${ }^{33}$ Alwi Shihab, Islam Inklusif (Bandung: Mizan, 1999), p. vii.
} 
in West is more isolated. It means that Islam will be difficult to be developed as a religion followed by the Westerner.

The latest challenge is Islamic State of Iraq and Syria (ISIS). As a politic organization, ISIS has destroyed the image of Islam in West that has ever been recovered after al-Qaeda. The brutal action of ISIS, not only for non-Muslim but also the Muslim itself, makes big uproar. It because the people who are not in line with the idea of ISIS are considered as a loser or unbeliever that can be punished by collective homicide. The bargaining position is frightened because all this time the militant strength of ISIS is getting stronger. In the last holy and precious Ramadan, ISIS used that event to spread the terrors in Quwait, Tunisia, dan Egypt. Moreover, when the Takbîr of 'Idul Fitri fills the air as a symbol of victory and happiness, ISIS continues their action to kill civilians in Iraq. The holy and happy day was changed becomes sad and mourn day because there are many Muslims killed. This global context should be our thoughtfulness because Islam as rahmat li al-âlamîn has been blackened by ISIS and the other extreme groups, by showing the face of Islam wildly and terrifyingly. They think that their group's understanding is the best and the right one, whereas the other groups' understanding are considered as losers, infidels, and called as al-takfiriyyûn, ${ }^{34}$ though they are Muslim too.

Because of the stronger action, ISIS gets the bigger territory. That achievement certainly gives a significant effect for the geopolitics of Islamic world, though we know that it will be a thread for Islam instead. Because, somehow, a blurred portrait played by ISIS has sparked a negative image for Islam. After the incident in September $11^{\text {th }} 2001$ in USA, Muslims keep trying to reinstate their good image. Various seminars and scientific discussions are always encouraged in order to create the Islam rahmat li al-'âlamîn, but after ISIS declaring as khilâfah Islâmiyah on $29^{\text {th }}$ June 2014, then the phobia of Islam bursts again. ${ }^{35}$

President Barack Obama, as the leader of the USA, strongly condemns the brutality of ISIS. A country considered as a human rights fighter, though the consistency is still questionable in the enforcement of human rights, has seen more than 1,429 people executed by the executioner of ISIS. They are innocent people. However, ISIS has concealed the truth. So that both non-Muslims and Muslims in their eyes are enemies as long as they disagree with their dogma.

However, we can see the geopolitics of Islamic world from the other side. The hard efforts done by ISIS, especially in controlling the territory of oil, give some advantages for Muslims because America and Europe have big authority to exploit the oil in most of Muslim areas. Hence, the presence of ISIS creates bitterness because the spirit of jihad developed by ISIS makes the immense love for Islam. Thus, the fighters of ISIS will furiously support

${ }^{34}$ Misrawi, "Meneguhkan Islam," p. 6.

${ }^{35}$ Ensiklopedia, "Negara Islam Irak dan Syam", http://id.wikipedia.ord., accessed, 20th October 2015. 
the Islamic area that has rich oil. The flaming spirit of jihad of ISIS threatens the West that is often considered as the exploiter of the natural wealth in Muslims' countries. ${ }^{36}$

The strength of ISIS to exploit the region rich of oil does not immediately give positive impact to the Islamic world. All this time, the idea developed by ISIS is very exclusive. They only agree with the perspective which is in line with them. It means that the Muslims who disagree with them are considered as a heretic and infidels. If ISIS still conceals themselves from others different perspectives, it will be difficult for them to make a good cooperation with other Islamic countries because the Muslims are fulminating their brutalism. Generally, Islamic countries look at ISIS as an Islam that does not represent 'rahmat li al-âlamîn'. Even there is an opinion said that ISIS is part of the West conspiracy as an effort to ruin the image of Islam in the world's view.

Apart from the polemics, geopolitically, the position of the Islamic world after alQaeda and ISIS, ${ }^{37}$ is increasingly considered by the world because the presence of Islam is regarded as the antithesis of the Western liberalism and capitalism. All this time, liberalism and capitalism are considered as the West effort to control the world. Therefore, the excluded people will be difficult to get their right of welfare. As a religion that is more demanded by the world, Islam becomes a threat to West for their big project. Islam has become an ideological movement that brings a new world order based on social justice. The spirit of world development that expected by Islam is the realization of civilized society with the presence of welfare, justice, and common security.

Though the image of Islam becomes worse because of al-Qaeda and ISIS, it does not reduce the spirit of Westerners who believes Islam as the right religion. Because of the barbaric actions committed by al-Qaeda and ISIS, the curiosity of Westerners about Islam actually is bigger and many of them want to learn more about Islam. They, who study the whole Islam, will get the right conclusions about Islam as a religion that is rahmat li al-'âlamîn.

The presence of al-Qaeda and ISIS should be considered as a movement system

\footnotetext{
${ }^{36}$ Harlan Cleveland, Lahirnya Sebuah Dunia Baru, transl. P. Soemitro (Jakarta: Yayasan Obor Indonesia, 1995), p. 50.

${ }^{37} \mathrm{Geopolitics}$ is the study of geography, history and social science that refers to the international relations. Geopolitics is necessary for each country to strengthen its position among other countries to get the important positions in the nation, or more expressly to put themselves in an equal position with other countries. Geopolitical studies found the first momentum after the World War 2, in which states at that time competed and fighted to conquer the other countries because of the power and politics. This study was firstly developed by Friedrich Ratzel (1844 to 1904). See Charles Hagan, "Geopolitics" in The Journal of Politics, Vol. 4, No. 4 (November 1942), p. 478. One country that became the starting point in the geopolitical issue was Germany during the World War 2 and some allied countries. According to Ratzel, there were two main issues in geopolitics; the space (the State) and position (politics). Both were behind the advent of World War One and Two. Look at George Kiss, "Political Geography into Geopolitics; Recent Trends in Germany," in Geographical Review, Vol. 32, No. 4 (October 1942), p. 636.
} 
that has double effects. As a religious social movement, both of them have created bad histories of Islam. However, on the other side, they actually strengthen the bargaining position of Islam as the great power of the world. The domination of the West all this time, especially for the attempt to exploit the natural wealth of the Islamic world, awakens the awareness of Muslims. Therefore, the thing that should be concerned in strengthening the geopolitical of Islamic world is by developing the critical thinking of transformative system in looking at the world space with the capitalism that only benefits a few people.

If Muslims brings religion as civilized movement in building civil society and then ignores such a brutal step like what have been done by Al-Qaeda and Islamic ISIS, the bargaining position will be further strengthened. Islam as a rahmat should be a theological doctrine that actuates the spiritual reasoning into reality. Our challenge, according to Hassan Hanafi, is to bring the theological conception of Islam as a social movement that enlightening, ${ }^{38}$ so that the goal of Islam to enlightens the world can be realized well.

If Islam becomes an ideological movement, the map of the world civilization will change. Thus, geopolitically, Muslims are greatly beneficial. Furthermore, the presence of Islam in the world will be more infatuating because it builds the spirit of common welfare as a part of the united people. Islam as rahmat li al-âlamîn expects the mercy of God not only for Muslims, but also for all creatures. Then, for non-Muslims, Islam is a blessing that will elevate their position in social, politic, education, and also economy. The symptoms about the revival of Islam in upholding the world civilization with the common spirit must be noticed optimistically because it is presented implicitly and explicitly in the idea of Islam Nusantara.

\section{Islam Nusantara and ISIS}

Islam Nusantara as a religious conception of Islam in Indonesia is the representation of the Islamic universal values. Therefore, the great desire of NU in the last $33^{\text {rd }}$ Muktarmar in Jombang is not a baseless project. The theme "Upholding Islam Nusantara Indonesia and World Civilization" is a conscious and basic effort in embedding the progressive of Islamic thought. ${ }^{39}$ The challenges of Islamic world after al-Qaeda and ISIS become greater,

${ }^{38}$ Hassan Hanafi, Dari Akidah ke Revolusi: Sikap Kita Terhadap Tradisi Lama, transl. Asep Usman Ismail (Jakarta: Paramadina: 2003), p. 15.

${ }^{39} \mathrm{~A}$ Rais Aam NU KH Mustafa Bisri found that Islam in the archipelago are developed and maintained through a network of clerics Ahlussunah wal Jamaah (Aswaja) in-depth knowledge and also deeply involved in community life in each neighborhood at once. Then the Muslim community formed is a Muslim community that is close to the guidance of the scholars, so that the behaviors reflect the dogma that emphasize the mercy. So simply, Islam Nusantara is the solution to the world civilization in the midst of crisis radicalism because Islam Nusantara has an Islamic view that called rahmatal lil Alamin. Read on, Mustafa Bisri, "Rais Aam PBNU: Islam Nusantara, Solusi Peradaban Dunia," in NU Online (Sabtu, 30 Mei 2015). 
because both have marred the position of Islam as the blessing religion to the universe. The image built by Al-Qaeda and ISIS is Islam as a sword religion. According to Fahmi Huwaydi, that image convinces the paradigm of people that Islam is a blade and religion is always defined as cutting off hands, war, hell, and other terrifying meanings. So it can easily cause the violence in life..$^{40}$

ISIS as a representation of radical Islamic movement has ignited more hatred against Islam. No one can presume that Islam as a religion that teaches the civility of life creates a conservative interpretation. Then, what has been done by ISIS from the attitude and action is not of Islamic values that bless the universe, but it is a religious arrogance under the pretext of jihâd. ${ }^{41}$ The action of ISIS probably is caused by psychological bitterness as a sequence of the Western pressure against Islam which is getting stronger. ${ }^{42}$ ISIS fights brutally under the pretext of jihad and the aim to build the glory of Islam by using Khilâfah Islâmiyah system. Academically, that system does not have a clear and definite source. The Qur'an and the prophet in the Hadith have never mentioned exactly about the government and politics system in Islamic world, ${ }^{43}$ but only mention about the urgency of leadership as an effort to make civilized society to be civilized society like what had been done by the Prophet Muhammad in Medina.

Islam Nusantara in Indonesia assumes that a leadership is not always Muslims and a country is not always Islamic. However, the most important thing is both leadership and country should give benefits to the society. Besides, in theological concept of Islam Nusantara, Indonesia is considered as the final state that has a valid leadership. Islam Nusantara regards the state as an instrument to create common benefits as the universal goals of Islam. ${ }^{44}$ The ijtihâd of Ulama' in formulating the concept of the state means to respond the pluralism of Indonesian people. So that, the result of the ijtihâd is not an Islamic state

${ }^{40}$ The consequences of silting to the universal values of religion are not only limited to discourse. More than that, at the empiric level, the subservience in front of the text brings the religious followers to the justification of doing destructive actions. Fahmi Huwaydi in al-Quran wa al-Sulthan gave an interesting view that the legacy of thought which inspired since several centuries ago has established a paradigm of propaganda that religion is the knife. Religion is always identified as the slauthering hand, war, hell, and other sinister meaning. Read on, Zuhairi Misrawi, "Menggagas Teologi Perdamaian," in http://islamlib.com (Minggu, 26 Mei 2002).

${ }^{41}$ Abdul Chalik, "ISIS dan Kita," in MAJALIS (Pebruari 2015) , p. 34.

${ }^{42}$ Zuhairi Misrawi, Pandangan Muslim Moderat: Toleransi, Terorisme, dan Oese Perdamaian, (Jakarta: Gramedia, 2010), p. 116.

${ }^{43} \mathrm{Abdul}$ Chalik, "Fundamentalisme dan Masa Depan Ideologi Politik Islam," in Islamica. Vol. 9, No. 1, 2014, p. 62.

${ }^{44}$ The spirit of Islam Nusantara's thought about the relationship between Islam and state is reflected in the attitude of Nahdlatul Ulama who believe that the important thing to Muslims in Indonesia is not an Islamic State, because the country is plural, but it is Darus Salam (Peace State), in which Muslims can apply the Syari'ah and religious activities. Read on, Said Aqil Siroj, Tasawuf sebagai Kritik Sosial: Mengedepankan Islam sebagai Inspirasi, Bukan Aspirasi (Bandung: Mizan, 2006), p. 273. 
but a divinity state. Ulama' decided to use a divinity state rather than Islamic State in order to maintain the social cohesion and integration among the different religions in Indonesia.

As we know that the system of ISIS movement led by Abu Bakar al-Baghdadi, all this time has been fighting hard for the upright of khilâfah Islâmiyah like what has been expected by Taqy al-Dîn al-Nabhanî through Hisbut Tahrir. ${ }^{45}$ The declaration of ISIS as khilâfah Islamîyah on the last June 2014 was the real action to control the Islamic world under a leadership. That religious perspective denies the reality of pluralism because in an Islamic state there will not be other religion except Islam. Psychologically, non-Muslims will be difficult to accept this reality and the other countries in the world can be gather to oppose the tyranny made by ISIS because it is considered as a violation of human right, especially in deciding a religion.

Actually, the dibatable relation between state and Islam is a classic issue in Islamic study because there is not concrete and certain explanation in al-Qur'an and Hadits that told about Islam as a religion and state, or merely a religion. ${ }^{46}$ Therefore, the scholars of Muslims put their rationalism only on the interpretation of reality that existed on the period of Prophet Muhammad and his companions afterwards. As a result, the different opinions about Islam and state become fierce and produce many political movements. As a representation of the ideological movement, ISIS assume that Islam and state must be one. That different ideology is still acceptable, but the violence ways committed by ISIS are not acceptable because it vilivies the name of Islam.

The view of ISIS is different from Islam Nusantara that conveys the dogma of Islam that is progressive and enlightening. In the reality developed in society, the perspective of Islam Nusantara gives more ways for people in understanding Islam as a value that brings common benefits. As an example of the relation between state and Islam, Islam Nusantara prioritizes Islam as a religion that can be freely expressed without creating an Islamic state. That thought is a form of progressive thought in responding the realities that exist in society.

One interesting figure of Islam Nusantara is Gus Dur. This eccentric Kyai tries to build the indigenous Islamic paradigm which can be categorized as the perspective of Islam Nusantara. Gus Dur builds the paradigm of Islamic using the term, universalism Islam, cosmopolitanism Islam, and the indigenization Islam. All those three are closely related. The universalism of Islam as a theoretical idea, Islamic cosmopolitanism as a dialogical thinking, and indigenization of Islam as the practice. Hassan Hanafi defines that the

${ }^{45}$ Ainur Rafiq al-Amin, "Transmutation of Ideology Gerakan Hizbut Tahrir," in Akademika, Vol. 16., No. 2, 2005, 110-115.

${ }^{46}$ Chalik, "Fundamentalisme dan Masa Depan," p. 62. 
faith should move from static to practice ${ }^{47}$. Gus Dur interprets the faith as a concrete step of common actions towards a civilized society. ${ }^{48}$

By taking the spirit of maqâsid al-syarîah, Gus Dur builds an Islamic paradigm with concrete foundations. First, the physical safety of citizens from body actions outside the law (hifdz al-nafs). Second, the safety of religious beliefs without any coercion to convert (hifdz al-dîn). Third, the safety of the family and descendants (hifdz al-nasl). Fourth, the safety of properties and personal properties from disruption or displacement beyond the legal procedures (hifdz al-mâl). Fifth, the safety of property rights and professions (hifdz al-milk). ${ }^{49}$

The thought of Gus Dur is a kind of concrete effort in defining Islam as a paradigm that builds civilized society. If the values spirit brought by Islam is clear, whatever the context exists in society, Islam will not be confused to give the polite formulation from the big mission as Islam. It can be seen clearly the difference between ISIS as the representation of radical Islamic movement and Islam Nusantara as the new Islamic paradigm from Indonesia.

In fact, Islam Nusantara brings the universal truth of Islam. The term "Islam Nusantara" is actually just a marker that means there is a progressive Islamic paradigm in Indonesia as the interpretation of Islamic texts from the local context developed. Then as a paradigm, Islam Nusantara does not require the others country to use the same term because it is actually a universal concept of Islam as rahmat li al-âlamîn. Specifically, refers to the statement of Jalaluddin Rahmat, Islam Nusantara is the actual Islam from the reality of the conceptual Islam that has been explained in the Quran and Hadith. According to him, only the actual Islam can change the history of Islamic civilization. ${ }^{50}$

Therefore, the intention of Nahdlatul Ulama to make Islam Nusantara as the paradigm of Islamic world does not intend to hegemonize the language and Islamic paradigm. However, Islam Nusantara intends to be universal idea of Islam as a religion that moves and becomes history of the reality. Therefore, the relation between Islam as a theological concept and the reality as a pedestal of life is not neglected. However, refers to the concept of Hassan Hanafi, Islam is not heaven concept, but a universal religion that should be grounded. ${ }^{51}$

${ }^{47}$ The modern theology movement emphasize the thinking on practical theology rather than theoretical theology by changing the theology to be an active force in moving a dignified human life. Read on Hanafi, Dari Akidah ke Revolusi, p. 15.

${ }^{48} \mathrm{Aksin}$ Wijaya, Menusantarakan Islam: Menelusuri Jejak Pergumulan Islam yang Tak Kunjung Usai du Nusantara (Yogyakarta: Nadi Pustaka, 2011), p. 190.

${ }^{49} \mathrm{Abdurrahman}$ Wahid, Islam Kosmopolitan: Nilai-Nilai Indonesia dan Transformasi Kebudayaan (Jakarta: The Wahid Institute, 2007), p. 3.

${ }^{50}$ Jalauddin Rahmat, Islam Aktual: Refleksi Sosial Seorang Cendikiawan Muslim (Bandung: Mizan, 1998), p. 18.

${ }^{51}$ Believing in God as the one creator in Islam is not enough if it is only in the heart, but it must be manifested concretely in action. The theological view in Islam must be presented to earth 
As a paradigm of Islam that successfully reconciles the contradictions by the reality and the culture developed in Indonesia, Islam Nusantara can be a model and a mindset that inspire Muslims in other countries without using the same term as 'Islam Nusantara'. It is because, Islam Nusantara brings a universal truth of Islam as rậmat li al-âlamîn like what have been brought by the Great Prophet Muhammad (peace be upon him).

\section{Conclusion}

The paradigm of Islam Nusantara as a representation of Islamic thought, rahmat li al-'âlamîn, discovers a very significant relevance in during the Islamic world crisis as a result of radical-fundamentalism movement done by al-Qaeda and ISIS all this time. The dream of Nahdatul Ulama' to make Islam Nusantara be the role model of the Islamic world civilization is not exaggeration. As the ijtihâd of scholars, Islam Nusantara has become part of a historical reality for Indonesian people's lives. Islam Nusantara that has a lot of Islamic heritage becomes a hope for the renaissance of Islamic world civilization. People in the world expect Indonesia to be the prototype of Islamic civilization in the contemporary era because of the people's characters that are multicultural, multi-religious, multiethnic, moderate, and tolerant than other Islamic countries.

Because of that reason, the position of Islam Nusantara in Islamic world geopolitics is in a high bargaining postion. Moreover, the existence of al-Qaeda and ISIS derived from the fundamentalism of Islam in Middle East devastate the Islamic world order from within. In this point, in the middle of multidimensional crisis that consists in Islamic world, the Islamic thought formed as Islam Nusantara is interesting to be noticed by the world. It has been proven that Islam Nusantara can be a role model of the civilization for Islam in Indonesia. So now, Islam can reconcile with the state, by implementing all the function in order to make a sovereign, just and prosperous society.

\section{References}

Abdalla, Ulil Absar. "Menyegarkan Kembali Pemahaman Islam," in Kompas, Monday, 18 November 2002.

Al-Amin, Ainur Rafiq. "Transmutation of Ideology Gerakan Hizbut Tahrir," in Akademika, Vol. 16., No. 2, 2005.

Arif, Syamsuddin. Orientalis \& Diabolisme Pemikiran. Jakarta: Gema Insani, 2008.

Ayoob, Mohammed (ed.). The Politics of Islamic Reassertion. London: Croom Helm, 1981. Azra, Azyumardi. "Islam Nusantara adalah Kita," in http://fah.uinjkt.ac.id, accessed 17th October 2015.

as liberation. Hassan Hanafi, "Ideologi dan Pembangunan," in Shonhaji Sholeh (ed.), Agama, Ideologi dan Pembangunan (Jakarta: P3M, 1991), p. 53-63. 
Bizawie, Zainul Milal. "Meneguhkan Islam Nusantara," in http://muktamar.nu.or.id., Jumat, 26 Juni 2015.

Chalik, Abdul. "Fundamentalisme dan Masa Depan Ideologi Politik Islam," in Islamica. Vol. 9, No. 1, 2014.

Chalik, Abdul. Islam dan Kekuasaan: Dinamika Politik dan Perebutan dalam Ruang Negara. Yogyakarta: Interpena, 2012.

Cleveland, Harlan. Lahirnya Sebuah Dunia Baru, transl. P. Soemitro. Jakarta: Yayasan Obor Indonesia, 1995.

EL-Mawa, Mahrus. “Teks dan Karakter Islam Nusantara,” in NU Online, Monday, 13 April 2015.

"Negara Islam Irak da Syam," in http://id.wikipedia.ord., accessed 20 October 2015.

Fuller, E. Graham \& Ian O. Lesser, A Sense of Siege. The Geopolitics of Islam and the West. Santa Monica: Westview Press, 1995.

Fealy, Greg \& Anthony Bubalo. Jejak Kafilah: Pengaruh Radikalisme Timur Tengah di Indonesia, transl. Akh Muzakki. Bandung: Mizan, 2007.

Hanafi, Hassan. "Ideologi dan Pembangunan," in Ed. Shonhaji Sholeh. Agama, Ideologi dan Pembangunan. Jakarta: P3M, 1991.

Hanafi, Hassan. Dari Akidah ke Revolusi: Sikap Kita Terhadap Tradisi Lama, transl. Asep Usman Ismail. Jakarta: Paramadina: 2003.

Hick, John. Problem of Religious Pluralism. London: The Macmillan Press, 1985.

Ja'far, Suhermanto. Filsafaf Perennial \& Titik Temu Agama-Agama. Surabaya: Elkaf, 2007.

Hagan, Charles. "Geopolitics," in the Journal of Politics, Vol. 4, No. 4, November 1942.

Kiss, George, "Political Geography into Geopolitics: Recent Trends in Germany," in Geographical Review, Vol. 32, No. 4 October 1942.

Kuntowijoyo. Paradigma Islam: Interpretasi untuk Aksi. Bandung: Mizan, 1991.

Latif, Yudi. Negara Paripurna: Rasionalitas, Historisitas, dan Aktualitas Pancasila. Jakarta: Gramedia, 2011.

M. Echols, John \& Hasan Shadily. Kamus Inggris-Indonesia. Jakarta: Gramedia, 1990.

Madjid, Nurcholish. Islam Doktrin dan Pradaban. Jakarta: Paramadina, 1992.

Misrawai, Zuhairi. "Meneguhkan Islam Nusantara," in Kompas, Saturday, 1 Agustus 2015.

Misrawai, Zuhairi. "Menggagas Teologi Perdamaian.” in http://islamlib.com, 26 Mei 2002.

Misrawai, Zuhairi. Pandangan Muslim Moderat: Toleransi, Terorisme, dan Oase Perdamaian. Jakarta: Gramedia, 2010.

Moesa, Ali Maschan. Nasionalisme Kyai: Konstruksi Sosial Berbasis Agama. Yogyakarta: LKiS, 2007.

Mustafa Bisri. "Rais Aam PBNU: Islam Nusantara, Solusi Peradaban Dunia." in NU Online, Saturday, 30 Mei 2015. 
MIQOT Vol. XL No. 2 Juli-Desember 2016

Nasr, Sayyed Hossein. The Heart of Islam, transl. Nurasiah. Bandung : Mizan, 2003.

Nasution, Harun. Islam Rasional. Bandung: Mizan, 1995.

Rahmat, Jalauddin. Islam Aktual: Refleksi Sosial Seorang Cendikiawan Muslim. Bandung: Mizan, 1998.

Rahmat, M. Imdadun. Islam Pribumi: Mendialogkan Agama dengan Realitas. Jakarta: Erlangga, 2003.

Saleh, Ahmad Syukri. Metode Tafsir al-Quran Kontemporer dalam Pandangan Fazlur Rahman. Jakarta: Gedung Persada Press, 2007.

Shihab, Alwi. Islam Inklusif. Bandung: Mizan, 1999.

Siroj, Said Aqil. Tasawuf sebagai Kritik Sosial: Mengedepankan Islam sebagai Inspirasi, Bukan Aspirasi. Bandung: Mizan, 2006.

Surahman, M. Anwar \& Marye Agung Kasmagi. 69 Konspirasi Amerika Serikat MemataMatai Dunia Versi Wikileaks. Jakarta: Raih Asas Sukses, 2011.

Syam, Nur. Islam Pesisir. Yogyakarta: LKiS, 2005.

Tibi, Bassam. The Challenge of Fundamentalism: Political Islam and the New Disorder. Berkeley: University of California Press, 1998.

Tjandrasasmita, Uka. Arkeologi Islam Nusantara. Jakarta: Gramedia, 2009.

Tobroni \& Syamsul Arifin. Islam Pluralisme Budaya dan Politik. Yogyakarta: Siprees, 1994.

Umar, Nasaruddin. "Apa Itu Islam Nusantara?," in Republika, Wednesday, 05 Agustus 2015.

Wahid, Abdurrahman, Islam Kosmopolitan: Nilai-Nilai Indonesia dan Transformasi Kebudayaan. Jakarta: The Wahid Institute, 2007.

Wijaya, Aksin. Menusantarakan Islam: Menelusuri Jejak Pergumulan Islam yang Tak Kunjung Usai di Nusantara. Yogyakarta: Nadi Pustaka, 2011.

Zahro, Amad. Tradisi Intelektual NU: Lajnah Bahstul Masail 1926-1999. Yogyakarta: LKiS, 2004.

Zaqzuq, Muhammad Hamdi. Reposisi Islam di Era Globalisasi. Yogyakarta: Pustaka Pesantren, 2001. 